\title{
The Others and the Croats in Early Medieval Eastern Adriatic History
}

\section{Abstract}

This paper examines the narrative strategies of the oldest two medieval Eastern Adriatic historical accounts regarding the emergence of the Early Medieval gentes in local history. Seen through the framework of Othering, these accounts display complicated images within images rather than a linear narrative. At the same time, two categories of the Other seem to appear in them - the present, preferable Other, and the past, undesirable Other. By employing such strategies, the two histories depict all the gentes in an almost identical manner, and in accordance with the established images, with only some layers of actual historical background[1]

Keywords: Middle Ages, Eastern Adriatic, medieval historians, Others, Croats

\section{Introduction}

“... multi christianorum ... eligentes magis cum eis sustinere persecutiones et penuriam et salvare animas suas, quam gaudere ad tempus cum gentilibus et vi eorum perdere animas" (CPD 1: 2830) ${ }^{[2]}$ Such severe accusations were brought in historical accounts from the High Middle Ages against those wicked gentes that were, at some point during the Migration Period, disturbing the "peacefully living" urban population of the Eastern Adriatic. Did the events mentioned in them really happen? If not, what was the point of a medieval historiographical narrative? Who were the gentes of those "dark ages," especially from the viewpoint of the High Medieval histories? ${ }^{[3]}$ To answer these questions in the following text, I will employ one among a variety of useful frameworks for understanding Early Medieval history of the Eastern Adriatic - that of Othering. To put it simply, Othering can be understood as a binary dichotomy of interrelationships between persons, social 
groups, and/or identities in dominant and inferior cultural positions, in which the notion of belonging becomes a crucial sign of one's social position. In such a formation of the Self and the Other, the process of the Othering provides evidence of the fashioning of the Self, its hidden desires and goals, through the stereotyping and scapegoating of the Other - weather positively or negatively and by being aware of the Other. In fact, the Self is revealed and constructed through the Other and in relation to the Other. In such a dynamic, the value judgment of the Other varies over time between inferior (most often) and equal. Depending on how distant they are from the Self, there can be more than one Other, although they are to some extent all the same because of their Otherness. The concept can be deployed in many ways, one of which is also the construction of the identity/ethnicity, particularly suitable in this case.$^{[4]}$ It is also a useful tool primarily in postcolonial medieval studies (or postcolonial theory applied to medieval societies). Although such use has been much debated, it seems to serve the purpose of interpreting various medieval cultural and social contacts, confrontation, and exchange (above all transculturation and hybridity), as well as medieval narratives ${ }^{[5]}$ I will proceed to examine the narratives of the two oldest historical accounts from the Eastern Adriatic area - Gesta Regum Sclavorum (CPD; also called Chronicle of the Priest of Diocleia $)^{[6]}$ and Historia Salonitana $(\mathrm{HS})^{7]}-$ about the Migration Period, with a focus on the emergence of Croats in the history of South-Eastern Europe. I aim to demonstrate the manner in which medieval historians used multi-layered strategies of Othering to present the past in a hierarchical order corresponding to the needs of their present. By doing so, two categories of the Other seem to appear - the present, preferable Other, and the past, undesirable Other. I hope that I will, at the same time, promote a more thorough (inter)textual analysis of the narrative corpora and symbol structures of both Eastern Adriatic medieval histories, as medievalists have so far predominantly discussed the facts and events in the form in which they were listed in the narratives of these histories (and their author, in the case of CPD) ${ }^{[8]}$

\section{Identity and the Other - Some Remarks}

From the Migration period until the formation of the regnum Chroatorum, several gentes can be identified clearly in the Eastern Adriatic coast and its hinterland. These most notable were the Goths, the Slavs, the Guduscani, and the Croati[9] The identity of the coastal cities varied through 
time, but they identified themselves either as Romani or as Latini[ ${ }^{10]}$ The sources have always portrayed the local elite in a position (culturally) superior to the populace in the hinterland. This superiority fueled the image of the elite as local guardians of traditional ways and the Roman identity. As identity constantly fluctuated, it was not of great importance whether that identity was inherited, imitated, constructed, or attributed, but that it was (discursively) articulated and that it eventually acquired boundaries in relation to other identities, which made it suitable for further development.

A variety of factors determined the identity of the gentes, such as geography, ethnography, customs, political and military allegiance, social position, religious affiliation, and even individual vocations or aspirations of the members of gentes, among others ${ }^{[11]}$ This multi-layered nature undoubtedly made the formation of identities an ever-changing and dynamic process that depended on the situation in a given area and time. Interaction and confrontation - especially with the superior socio-economic power - further stimulated the formation of identities, while transculturation could have led to the appearance of multiple identities. In fact, most of the identities became clear only when confronted with a superior power (in the late antiquity and the early middle age, such were the Roman, Byzantine, and Frankish Empire) ${ }^{[12]}$ One must also bear in mind the factor of homogenization and cohesion with which the new identities might have been perceived within the given empire. It seems that cultural translation during Late Antiquity and the Early Middle Ages had profoundly changed both the gentes and the Roman Empire, producing and transforming a variety of identities. Many of them were eventually simplified, categorized and generalized, thus entering the "common knowledge" as generic notions. It seems that the especially (if not the most) important element for the existence of an identity was the perception of an individual's allegiance to a wider community - one's sense of belonging. A clear distinction between the Self and the Other was the main factor of differentiation between individuals and communities ${ }^{[13]}$

\section{Eastern Adriatic Medieval Histories}

Previously mentioned are the categories of understanding the writings of the CPD and HS. Both drew their data from some today lost and unknown sources and, as I shall explain, from "common 
knowledge," or rather collective memory ${ }^{[14]}$ It is worth noting that the CPD is probably older among the two, although the historiographical discussion about its origin ${ }^{[15]}$ as well as about who the Priest of Diocleia really was ${ }^{[16]}$ is still ongoing. Unlike the CPD, which is mostly composed as a res gestae, the HS is composed as a chronica. The HS was the work of Thomas, archdeacon of Split, dating from the mid-thirteenth century ${ }^{[17]}$ Thomas was a highly educated member of Split's elite and, at one point, the most influential ecclesiastical figure in the town, deeply involved in a great many affairs. In his work - the most extensive chronicle of the Croatian Middle Ages - on the history of the archbishops of Salona and Split from the beginnings of the (arch)bishopric in the late antiquity up to his own time, he exhibited evidence concerning the privileges the medieval see of Split had supposedly inherited from the ancient metropolitan see of Salona, in order to justify the primacy of the Church of Split on the Eastern Adriatic and in the Croatian hinterland. As Thomas based his work on, among other things, the documents available in the Chapter of Split during his time ${ }^{[18]}$ his work is very valuable to a historian. In any case, by using the same topoi, both of these works depict the early migrating gentes (Goths, Slavs, Croats) as bloodthirsty invaders and oppressors of the population living in coastal cities:

(CPD 1):

... thousands of Christians died of the sword and a great many were taken into captivity. ${ }^{[19]}$

Many injustices and persecutions were committed against the Christians living in coastal cities. ${ }^{[20]}$

... Ratimirus, his son, who was since his childhood a great enemy of Christians. He started to persecute them unboundedly and wanted to vanquish their very name from the face of the earth and from his kingdom. He also destroyed many of their towns and places, and those who he spared he reduced to servitude.21]

In that time, Christians were constantly persecuted and, as they were enemies and persecutors of Christians, we think it would take too long to describe their unjust acts and lives, because we hasten towards better and more pleasant writings.[22] 
Many of the Christians ... chose rather to suffer persecution and poverty with them, and to thereby save their own souls, than to rejoice temporarily with the pagans and to thereby condemn their own

$$
\text { souls! }{ }^{[23]}
$$

(HS):

So they [the Goths] settled there [in Croatia], and began to oppress the natives and by force to reduce them to servitude. (37)

The enemy burst into the city forthwith, and ceaselessly attacked those fleeing from behind, hunted for plunder, spared no one that they came across, and set fire to the houses. Soon the wretched city, deprived of the protection of her sons, was filled with a hostile people; there was no one who would have mercy on the churches or the ancient buildings and beautiful palaces, but rather the enemy in the fury of their attack set fire to everything in the city, and in one brief hour reduced the whole to coals and ashes. (41-43)

Afterwards they began little by little to venture out and to cultivate the lands close to their settlement. But when the leaders of the Goths heard that the citizens of Salona had returned from the islands, they at once led an army against them, laying waste all that they had cultivated and not allowing them to venture outside of their walls. Then the citizens took counsel among themselves and sent a delegation to the emperors in Constantinople, asking and entreating that they might be allowed to live in Split and retain the territory of their city of Salona by their former right. And so, indeed, it came about. The delegates were granted everything that they wanted, and returned to their fellow citizens carrying the sacred rescript of the noble rulers. And a command was sent to the chiefs of the Goths and the Slavs, strictly forbidding them to trouble the citizens of Salona who were now living in Split. (53)

When they received this order from the emperors, these people no longer dared to make war on the Spalatins. Then peace was made between them, and little by little the people of Split began to have dealings with the Slavs, to carry on business and trade, to intermarry, and to cause them to be peaceful and friendly towards them. (53) 
Before analyzing the obvious differences between the two narratives, it is important to note that the "Gothicism" was very appropriate as a means of storytelling for both the CPD and the HS, precisely because it, among other things, at its core included the most common medieval Other - the heretics. In addition to being a late antique catch-all term for various migrating gentes ${ }^{[24]}$ the term "Goth," because of the actual groups' Arian heresy, also functioned as a common denominator for any past religious dissent. This became especially important during the period from the 11 th to the 13th century, due to the postulates of the Gregorian Reform and the renewed religious zeal against all who espoused non-Christian ways (Matijević Sokol, Toma Arhiđakon 235-40, 267; Džino 100), whether they were Christians or heretics. This is precisely the context of the "Gothicism" in both the $\mathrm{CPD}$ and the HS, but the problem of a possible intertextual relation between them, for example, through some older narrative templates they both relied on ${ }^{[25]}$ or simply because the authors belonged to the same cultural background, remains open. The problem of the CPD's "Gothicism" was most recently addressed by Denis E. Alimov ("Gotsko-Slavjanskoe"). Although he considered the problem in a much broader context than this paper does, he pointed out that the ethnicity in the CPD (the Goths and the Slavs) is the fruit of its author's discursive structuring of contemporary realities - among which the town-hinterland distinction is clear - in ethnic categories, and of their projection in the past. His conclusions are closely related to Kowalski's search for the construction and representation of the schematic tales and narrative structures in the CPD, as well as to some parts of Francesco Borri's ("Arrivano i barbari") (inter)textual analyses of both the HS and the CPD regarding the destruction of Salona. In the following I will make use of their conclusions by applying the methodological concept of Othering.

The HS focuses on the history of Split. To the Christians of the CPD, the HS counterposes the people of Salona. The HS stresses more clearly the civilizational level of the coastal cities (that is, of Split) and their direct connection to the imperial power. Nonetheless, after the description of the wickedness of the "Goths" and the "Slavs," there comes a clear-cut shift in their depiction in both chronicles. As the chronicles put it, Christianization was the final turning point in the attitude of the gentes toward the population of the coastal cities. Only after their Christianization the "Goths" and the "Slavs" became a part of the civilized world, to which the urban population have already belonged. From the viewpoint of the citizens, that was the necessary precondition for even trying to 
comprehend the gentes. Until that point, the gentes were perceived according to the "barbarology," [26] that is, in terms of the process of Othering! ${ }^{[27]}$

The express focal points of contrast as presented in the CPD and the HS can be defined as follows: Christians - pagans, civilization - barbarism, culture - savagery, sophistication ruthlessness and, finally, Empire/tradition - non-empire/primitivism.

The latter is probably the most important contrast because, as Archdeacon Thomas stated, the role of the emperor (that is, the force of law) was crucial for the pacification of the situation. I must add that at that time it was not very important whether that was the Byzantine emperor(s), as Thomas stated, or the Carolingian one. The subject of Thomas's writing is also not very important - he was himself convinced that he was writing about the destruction of Salona, as the titles of his chapters show, and he was set on proving the unbroken succession in the Archdiocese of Salona-Split. However, the manner in which he was writing about it is important. In the following, I will explain why.

Thomas himself provides the explanation of his account of the destruction of Salona. He states: "I shall attempt to explain it partly from writing, partly from hearsay, and partly by relying upon conjecture" (HS 34). This was the usual manner of High Medieval scholarly writing and ${ }^{[28]}$ of course, Thomas drew his knowledge from the older writings available to him - and, when he was describing events from the eleventh century onwards, from the documents preserved in the Chapter of Split. However, the element of "hearsay" (or the common knowledge that was somehow relayed to Thomas) is usually based on general, sometimes stereotypical views, especially regarding the distant past. How, then, is "hearsay" recognizable in Thomas's work?

As Thomas was a member of an urban elite, to some extent, he projected the relations between the town and the countryside of his own time into the past. His viewpoint was that of Split, particularly of the elites and the Archbishopric of Split. In other words, the urban-rural dichotomy mirrors the Othering that existed in Thomas's time. On the other hand, the "barbarology" in Thomas's work must have had some "historical" background. In fact, Thomas used the manuscript from the second part of the eleventh century known today as Žiće sv. Dujma (The Passion of St. Domnius), which is the oldest known source that mentions the Goths as the destroyers of Salona 
and the oppressors of its population. This shows that a widespread "barbarology" targeting the gentes already existed in the eleventh-century Split. As Francesco Borri has shown ("Arrivano i barbari"), this was the case in both Venice and Dubrovnik, and in the absence of "writing," barbarian heroes (Attila and Totila, in an obscure meld of deeds attributed to them) were used to bridge the discontinuity. If one takes into account the fact that the Passion is probably older than the eleventh century - or that it at least expresses the acceptable "common knowledge" of an older time - it is evident that, regarding "barbarology," the viewpoints of "civilized" Europe and those of the Eastern Adriatic coastal towns already corresponded at a very early date. This brings me to the following conclusions.

\section{4. "Barbarology"; Goths $\rightarrow$ / Slavs $\rightarrow$ Croats}

It seems that the "barbarology" in Eastern Adriatic medieval histories is the product of a certain model of its authors' treatment of the past. According to that model, there had to be the Others to permanently reaffirm the self-identity of the viewpoint community. That was why the wickedness of bloodthirsty invaders had to be invented. The genesis of a self-identity, when contrasting "barbarians" with the "civilized world," was even more important as the gentes became participants in that same identity. But after a certain point, there were not many Others left in the present. Therefore, the Others to be scapegoated had to remain in the past (or to be moved into a more distant past), while new aspects of Othering entered the picture, most likely on a less general and more suitable level. After the gentes adopted Christianity and became subjects of the Emperor, the general level of Othering was projected into a description of their past. Of course, that kind of view had, with time and the transmission of the written word, become "common knowledge" and a customary way of writing about the past. That is why the Passion of St. Domnius mentions Goths. On the other hand, when adopting a more suitable level of Othering, the Eastern Adriatic medieval historians had to make a clear cut in their depiction of the gentes. Therefore, new identities emerged in their narratives, at first depicted sometimes disapprovingly and sometimes approvingly, but never as disapprovingly as the migrating gentes had been. To put it more simply, in lan Wood's words, "in the divine scheme of things ... especially a Christian barbarian could be a force for good" ("The Term 'barbarus'” 41) - but he was still a barbarian, nonetheless. The path of the 
narrative and the construction of identity in the two Eastern Adriatic medieval histories were as follows: Goths $\rightarrow$ / (to; or) Slavs $\rightarrow$ (to) Croats.

All this considered, it is reasonable to ask who were, then, the Others, and who the Us? The answer will probably never be clear as it depends on the viewpoint, but, interestingly, the Croats were the definite identity that emerged during this period of history. However, from the Eastern Adriatic medieval historians' point of view, in that period, the Croats were also the Others, but a preferable kind of Others. Moreover, at the time when Archdeacon Thomas and the author of CPD were writing, the Croatian identity was widespread, so the Othering had to be moved into a more distant past. Besides, during Thomas's lifetime, there was all kind of candidates for becoming the Others - such as the nonurban population of the coastal hinterland, the town of Zadar and its residents, or the "Croatian" episcopat $e^{29]}$ - who were then clearly visible and therefore more important than the distant past. The depiction of the early migrating gentes as bloodthirsty invaders and oppressors was a form of the narrative, a strategy to produce the desired effect on the reader, and a way of strengthening an existing identity or even forming a new one ${ }^{[30]}$ The latter is primarily seen in the HS, considering its unease with the narrativization of the history of the Croatian identity, which Thomas had to reconcile with the Croatian identity of his time, his own views on reality, and the story of the destruction of Salona.

He achieved all this by using the literary template of the legendary Curetes/Corybantes, whom he considered ancient the predecessors of the Croats (HS 36-39). Thomas portrays them as wild, ferocious, warlike, but also naive indigenous people. With the newly arrived Goths, they formed new gens ("permixti ergo sunt populi isti et facti sunt gens una"; HS 38), became Christians, "albeit extremely primitive ones," but some of them were also infected with Arianism. Thomas concluded that many called these new gens "Goths, but also Slavs" (Ibid.). In this part, Thomas's narrative is truly remarkable for its use of Othering. He applied all of the stereotypes of "barbarology," but at the same time demonstrated an utmost consideration for the Croatian identity, in which he saw the Croats of his time. Thus, in the past, the Croats were indigenous to the hinterland of the Eastern Adriatic coastal towns and were primitive Christians (which, from the point of view of an archdeacon and an intellectual, they still were in the 13th century). They were Christian barbarians - and as such were able to perform good deeds - but the Goths made them heretics, and therefore 
they fell back into barbarism, not only due to heresy but also because they indulged in nonChristian behavior. ${ }^{[31]}$ Furthermore, due to such developments, they lost their name and came to be known as Goths/Slavs. In a way, Thomas sympathized with and justified the predecessors of the Croats, precisely because he was surrounded by the Croats of his time, although he incessantly expresses his (social, intellectual, religious, and cultural) superiority over the latter, who were, after all, from his point of view, still the barbarian Other. Nevertheless, the whole episode primarily shows how the needs and views of Thomas himself (and of his cultural environment) decisively influenced his vision of the past and how Thomas constructed the narrative identities. The concept of narrative identities is another useful tool for understanding both the CPD and the HS. As Paul Ricoeur ("Oneself as Another" 140-68; "Time and Narrative" 241-74) defined it based on a theory of the narrative, the concept seeks a dynamic relationship between the variability and the permanence of identity. In this process, the identity emerges through the narrative, and the narrative identity for an individual and a community gives form to their specific sense of self. The narrative identity is thus formed by the complex merging of an individual experience of time and a narrativization of the past into a meaningful (causal) whole, in which both the text (the writer) and the reader - by the ability to internalize existing narratives into their own - create an understanding of self. The Goths, Slavs, and Croats in the CPD and the HS should primarily be viewed through the strategy of organizing the story and as narrative identities created through the internalization of different narratives into a sense of self. As mentioned above, these identities primarily reveal the worldviews contemporary to the Eastern Adriatic medieval histories, with only some layers of (actual) identities.

Furthermore, all that is stated above corresponds to the medieval understanding of time. According to Hans Werner-Goetz, the genre of historical writing included: generalization (selection of the events worth remembering), the voice of truth (that differentiated historiography from fiction), examination of the past (that separated historiography from prophecies about the future), preservation of the past for posterity, and narrative representation in chronological order ("The Concept" 143). Exactly that chronological order and narration of facts were the essence of history. Also, history only made sense in the context of teleological representation, the temporal progression toward salvation, and not as a precise reference to a specific time in the past. This 
timelessness - despite the apparent chronological order of the narration - enabled the use of the past for the purposes of the present, and, at the same time, erased the historicity of the past. Thus, the past only served as a collection of exemplary events, and with its unchanging, timeless character, strengthened the position of the present in the teleology of salvation. It was exactly the act of Christianization that made an unparalleled exemplary event in the medieval worldview. Through recreating that event, despite still being the Others, the gentes, again and again, became the present, preferable Others, unlike the ones before the Christianization, who had to be depicted as the past, undesirable Others.

All this does not mean that some problems involving the "Goths," or the "Slavs," did not exist, only that they were arranged to fit the narrative in accordance with "common knowledge" or, as Thomas put it, "hearsay." This "hearsay" abridged various events from the past - and the various sources the Eastern Adriatic medieval historians had used - and combined them into a clear narrative that focused on, among other things, the Croats.

With all this in mind, it is also reasonable to ask whether there was any historical background to the narrative of CPD and HS, and if so, what was it?

\section{The Historical Background}

To answer this question, I must make some additional remarks about the "Goths" and the "Slavs." Viewed from the Roman perspective, the notions of "Goths" and "Slavs" did not, at least to a point, denote homogenous entities but were rather broad notions used to describe various heterogeneous groups in various stages of social formation and different forms of interaction with the Roman world. Following Patrick Amory's (277-320) line of thinking, it can be stated that the condition of political allegiances could consequently lead to one being perceived as a "Goth" or as a "Roman." In the same way, it is indeed interesting that the term "Sclavenes" appears precisely during the time of Emperor Justinian l's renovatio and its implementation of a new Romanness identity. It is reasonable to ask whether - in the context of a significant increase in direct contact and warfare on the Danube frontier (Curta, "The Making of the Slavs" 74-189) - the notion of "Sclavenes" was overemphasized, or whether it was, perhaps, a construct of the high East Roman political circles for whom Procopius, the first one to ever mention Slavs, was a sort of a spokesman 
(Greatrex). This overemphasis could have had several implications for Eastern Roman society, especially concerning the situation of the Gothic Wars. As "Slavs" were a numerous, warlike population which was, among others, directly threatening Constantinople ${ }^{[32]}$ and, at the same time, the whole of the Central and Eastern Balkans, the implications of the notion of "Sclavenes" for the homogenization of the Eastern Roman society amid the Gothic Wars are obvious. The notion of Sclavenes can be viewed from yet another angle. In a way, the Sclavenes could have represented a counterbalance to the "Goth" identity, especially if the former was a generic identity and the latter a political identity. In any case, it can be stated that the "Slavs" and "Sclavenes" were, to some point, a product of the "imperial discourse."

The Goths of the CPD and HS are probably connected to the Ostrogothic military affairs in Dalmatia during the 530s and 540s. As was mentioned previously, in the 540s, Salona was a military base for the Byzantines during the Gothic Wars and one of the staging points for their attacks on Italy.[33] Although the military actions of the Goths did not cause the complete destruction of Salona, the influence of these military affairs on the collective memory is not negligible, especially if one takes into account the almost complete lack of historical sources from the 7th and the first half of the 8th centuries. It was precisely this lack of sources that prompted the chroniclers to produce something out of nothing, and so the Goths - who disappeared after the Gothic Wars - had to be replaced with "Slavs."

In fact, the writers' understanding of the term corresponded to the "imperial discourse" or "barbarology" about the "Slavs." This discourse became common in the "civilized" Europe as the identifier of belonging to the common identity and the main label of its connection with the Roman past (Whalin 151-66, 271). The case of the Eastern Adriatic coastal towns undoubtedly fitted the latter category. Therefore, the "Slavs" of chronicles do not reflect only the discourse of the sources their writers used. The "Slavs" also reflect the notion used in the past - and through time became common knowledge, or "hearsay" - for the stark differentness of the Others before they acquired the precondition for being included in Self. These Others did not necessarily have to actually be Slavs, and they most likely were not - they were certainly not Goths either - but they were described as Slavs due to the local implementation of the "imperial discourse" on the time and space covered by the veil of two hundred years of silence. 
It is important to point out another development of the 11th and 12th centuries that might help with placing Thomas's "hearsay" in a broader context. It was precisely during the 12th century that a new expression of Romanness gradually (re)emerged. It was still a discourse of the social and cultural elite, primarily based on a shared literate culture, but now it started to include an ethnic notion of Romaness (Stouraitis, "Roman Identity"; Stouraitis, "Byzantine Romanness"; Stephenson, "Byzantine conceptions"). The influence of this new discourse and the corresponding political practice of renovatio imperii on the Eastern Adriatic during the second half of the 12th century should not be neglected, ${ }^{[34]}$ especially if viewed according to Burkhartd's (48-49) concept of imperial communities: the presence of imperial officials in Split, the mimicry of the local elite and the personal ceremonial ritual of the Split's archbishop's visit to the emperor in Constantinople, the imperial effective control over resources, and its active hegemony ${ }^{[35]}$ all clearly visible from HS (118-24). It seems plausible that the renewed Romanness boosted the dormant or/and transformed - through centuries of cultural assimilation and appropriation vis-à-vis the people of the hinterland - the Romani identity of the coastal cities ${ }^{[36]}$ Nonetheless, as the coastal cities again became a part of the imperial Roman community, the perception of the local perseverance of traditional (Roman) ways - which, at that time, were only a part of the narrative identity - became the focus of self-categorization. This self-perception was, however, primarily constructed through a local urban-nonurban dichotomy ${ }^{[37]}$ which was further discursively identified with the ethnic notion. By then, the Othering had to be rearranged, with special attention toward the ethnic notion of the then dominant local identities. It seems that these were the cultural and social preconditions for the origin of both HS and CPD and their representation of the past. The evil, heretical, non-urban barbarians were labeled as "Goths," while "Slavs" were the good, Christian, non-urban barbarians such as Croats, and the Roman, Christian (civilized) city dwellers as "Romani." Thus, the disposition of both Eastern Adriatic medieval histories toward the "Goths," the "Slavs" and the Croats were twofold. On the one hand, while imagining the past, the histories were using a mixed intellectual discourse of the Romanness and the identity transformation of the local elite, but on the other hand, the fact that HS described the Croats as a preferable kind of Others indicates that imperial universalism in the local context - perhaps only visible in some literary forms to a historian - was long gone. 


\section{The Croats and/as the Other - Final Remarks}

According to the process of incorporating the Other in a self-identity, the influence of the Carolingian world was of utmost importance for the formation of ethnic identities along the southeastern frontier of the Carolingian world. Their coming out of the silence of historical sources coincided with the increase of Frankish interest in the wider Eastern Adriatic region. In the aftermath of the destruction of the Avar state, the 812 Treaty of Aachen and the establishing of a modus vivendi between the Carolingian and Byzantine Empires, a variety of micro-gentes emerged along the frontier of the Carolingian Empire. This was especially evident after 817 when the final demarcation of the borders between the Carolingian and the Byzantine Empire took place. The earliest detailed written testimonies on the political and social situation in the wider Eastern Adriatic region are Frankish ones, so it is not surprising that many of these gentes stood in a kind of a satellite relation toward the Carolingian Empire. Such were the Carniolenses, Carantanos, Timociani, Guduscani, as well as the unknown subjects of the bearers of the titles of dux Pannoniae inferioris, dux Dalmaciae, and dux Dalmatiae et Liburniae. Eventually, by the 830s, one of the gentes became dominant in the Eastern Adriatic hinterland - the Croats ${ }^{[38]}$

The emergence of these gentes and, finally, the Croats in the Frankish narrative was possible only after they became part of "civilized" Europe, or, in other words, acknowledged by the master identity as being worth noticing. Thus, the new identities were formed only after the Frankish worldview was adopted, and they would eventually enter the narrative accordingly. The main feature of this worldview was Christianity. Exactly this, among other things mentioned here, is echoed in the description of the Croats as a preferable kind of Others.

The understanding of the distant past in CPD and HS is primarily based on common knowledge and the creation of narrative identities. Different events from the past were combined into a clear narrative with a familiar meaning and predefined goals of positioning the present in the teleology of the salvation. The Goths from the 6th century, the Slavs from an unknown early medieval time, and the Croats from the 9th century were almost the same in that narrative and could be tied to any events interchangeably! ${ }^{[39]}$ If viewed in that light, there are only some layers of an actual historical 
background in CPD and HS. It seems that Othering is a useful framework for identifying those layers properly. At the same time, that framework puts forward distinctive categories of Others according to their existence at certain points in history. In the case examined here, the present, those were the preferable Others and the past, undesirable Others.

\section{Works Cited}

Agapitos, Panagiotis A., and Lars Boje Mortensen, editors. Medieval Narratives between History and Fiction: From the Centre to the Periphery of Europe, c. 1100-1400. Museum Tusculanum, 2012.

Alimov, Denis Evgenievič. Этногенез хорватов: формирование хорватской этнополитической общности в VII-IX вB (Etnogenez Horvatov: formirovanie horvatskoj etnopolitičeskoj obščnosti v VII-IX vv). Nestor-Istorija, 2016.

Alimov, Denis Evgenievič. “'Готско-славянское’ королевство: раннесредневековый Иллирик в дискурсивном пространстве этнопоэзиса” (“Gotsko-Slavjanskoe korolestvo: reannesrednevekovyj Ilirik v diskursivnom prostranstve etnopoezisa"). Vestnik Udmurtskovo Universiteta, vol. 27, no. 4, 2017, pp. 516-25.

Althoff, Gerd, et al., editors. Medieval Concepts of the Past: Ritual, Memory, Historiography. Cambridge University Press, 2002.

Altschul, Nadia. "Postcolonialism and the Study of the Middle Ages." History Compass, vol. 6, no. 2, 2008, pp. 588-606.

Amory, Patrick. People and Identity in Ostrogothic Italy, 489-554. Cambridge University Press, 1997.

Ančić, Mladen. "Church with Incomplete Biography Plans for the Consolidation of Byzantine Rule on the Adriatic at the Beginning of Ninth Century." Byzantium, Its Neighbours and Its Cultures, edited by Danijel Džino and Ken Parry, Australian Association for Byzantine Studies, 2014, pp. 7188.

Ančić, Mladen. “Dux nomine Reles: How did Emanuel Komnenos' Imperial Machine Function?" 
Byzantium in the Adriatic from the 6th to 12th Century, 28-30 September 2018, Museum of Croatian Archaeological Monuments, Split, Croatia. Conference Presentation.

Ančić, Mladen, et al., editors. Imperial Spheres and the Adriatic: Byzantium, the Carolingians and the Treaty of Aachen (812). Routledge, 2018.

Bak János M., and Ivan Jurkovic, editors. Chronicon: Medieval Narrative Sources: A Chronological Guide with Introductory Essays. Brepols, 2013.

Barth, Fredrik. "Introduction." Ethnic Groups and Boundaries: The Social Organization of Cultural Difference, edited by Fredrik Barth, Little, Brown and Company, 1969, pp. 9-38.

Bartra, Roger. Wild Men in the Looking Glass: The Mythic Origins of European Otherness. Ann Arbor, 1994.

Basić, Ivan. "The Sarcophagus with Sanction-Formula from Trogir (Aspects of the Byzantine Diplomatics Tradition in Early Medieval Epigraphy of the Adriatic)." Vjesnik za arheologiju i historiju dalmatinsku, vol. 111, 2018, pp. 281-330.

Black, Antony. "The Individual and Society." The Cambridge History of Medieval Political Thought C.350-C.1450, edited by J. H. Burns, Cambridge University Press, 1988, pp. 588-606.

Booker, Courtney M. "Reading a Medieval Narrative: An Accessus." Chronicon: Medieval Narrative Sources: A Chronological Guide with Introductory Essays, edited by János M. Bak and Ivan Jurkovic, Brepols, 2013, pp. 35-67.

Borri, Francesco. "Arrivano i barbari a cavallo! Foundation Myths and Origines gentium in the Adriatic Arc." Post-roman Transitions: Christian and Barbarian Identities in the Early Medieval West , edited by Walter Pohl and Gerda Heydemann, Brepols, 2013, pp. 215-70.

Borri, Francesco. "Dalmatian Romans and Their Adriatic Friends: Some Further Remarks." Transformations of Romanness, edited by Walter Pohl et al., De Gruyter, 2018, pp. 241-52.

Brenner, Elma, et al., editors. Memory and Commemoration in Medieval Culture. Routledge, 2016.

Budak, Neven. "Identities in Early Medieval Dalmatia (Seventh-Eleventh Centuries)." Franks, Northmen and Slavs: Gentes and State Formation in Early Medieval Europe, edited by Ildar H. Garipzanov et al., Brepols, 2008, pp. 223-41. 
Bujan, Solange. "La Chronique du prêtre de Dioclée. Un faux document historique." Revue des études byzantines, vol. 66, 2008, pp. 5-38.

Burkhardt, Stefan. "Between Empires: South-Eastern Europe and the Two Roman Empires in the Middle Ages." Medieval East Central Europe in a Comparative Perspective from Frontier Zones to Lands in Focus, edited by Gerhard Jaritz and Katalin Szende, Routledge, 2016, 47-61.

Carruthers, Mary. The Book of Memory: A Study of Memory in Medieval Culture. Cambridge University Press, 2008.

Choniates, Nicetas. Nicetae Choniatae Historiae. Edited by Jan Louis van Dieten, De Gruyter, 1975.

Ciglenečki, Slavko. “Justinijanovo utvrđivanje Ilirika.” Archaeologia Adriatica, vol. 3, 2009, pp. 20522.

Clanchy, M. T. From Memory to Written Record, England 1066-1307. 3rd ed., Wiley-Blackwell, 2013.

Classen, Albrecht. "Introduction: The Self, the Other, and Everything in Between: Xenological Phenomenology of the Middle Ages." Meeting the Foreign in the Middle Ages, edited by Albrecht Classen, Routledge, 2002, pp. xi-Ixxiii.

Cohen, Jeffrey Jerome, editor. The Postcolonial Middle Ages. Palgrave, 2001.

Coleman, Janet. Ancient and Medieval Memories: Studies in the Reconstruction of the Past. Cambridge University Press, 1995.

Constantine Porphyrogenitus. De Administrando Imperio. Translated by Romilly James Heald Jenkins, edited by Gyula Moravcsik, Dumbarton Oaks Center for Byzantine Studies, 1967.

Curta, Florin. "A note on trade and trade centres in the eastern and northern Adriatic region between the eighth and the ninth century." Hortus Artium Medievalium, vol. 16, 2010, pp. 267-76. Curta, Florin. Eastern Europe in the Middle Ages (500-1300). Brill, 2019. 2 vols.

Curta, Florin. "Some Remarks on Ethnicity in Medieval Archaeology." Early Medieval Europe, vol. 15, no. 2, 2007, pp. 159-85. 
Curta, Florin. Southeastern Europe in the Middle Ages 500-1250. Cambridge University Press, 2006.

Curta, Florin. The Making of the Slavs: History and Archaeology of the Lower Danube

Region, c.500-700. Cambridge University Press, 2001.

---, editor. The Other Europe in the Middle Ages. Brill, 2008.

Deliyannis, Deborah Mauskopf. "Introduction." Historiography in the Middle Ages, edited by

Deborah Mauskopf Deliyannis, Brill, 2003, pp. 1-13.

Džino, Danijel. Becoming Slav, Becoming Croat: Identity Transformations in Post-Roman and Early Medieval Dalmatia. Brill, 2010.

Džino, Danijel. From Justinian to Branimir: The Making of the Middle Ages in Dalmatia. Routledge, 2020.

Džino, Danijel, et al., editors. Migration, Integration and Connectivity on the Southeastern Frontier of the Carolingian Empire. Brill, 2018.

Fentress, James, and Chris Wickham. Social Memory. Blackwell, 1992.

Ferluga, Jadran. L’amministrazione bizantina in Dalmazia. Deputazione di storia patria, 1978.

Galović, Tomislav, and Damir Agičić, editors. Klaić i njezin znanstveni i nastavni doprinos razvoju historiografije, 29-30 Nov. 2013, Zagreb, Croatia, FF Press, 2014, pp. 171-89.

Garipzanov, Ildar H., editor. Historical Narratives and Christian Identity on a European Periphery: Early History Writing in Northern, East-Central, and Eastern Europe (c. 1070-1200). Brepols, 2011.

Garipzanov, Ildar H., et al. "Introduction: Gentes, Gentile Identity, and State Formation in Early Medieval Europe." Franks, Northmen and Slavs: Gentes and State Formation in Early Medieval Europe, edited by Ildar H. Garipzanov et al., Brepols, 2008, pp. 1-5.

Gaunt, Simon. "Can the Middle Ages Be Postcolonial?" Comparative Literature, vol. 61, no. 2, 2009, pp. 160-76.

Geoffrey, Greatrex. "Perceptions of Procopius in Recent Scholarship." Histos, vol. 8, 2014, pp. 76121. 
Gillett, Andrew, editor. On Barbarian Identity: Critical Approaches to Ethnicity in the Early Middle A ges. Brepols, 2002.

Goetz, Hans-Werner. "The Concept of Time in the Historiography of the Eleventh and Twelfth Centuries." Medieval Concepts of the Past: Ritual, Memory, Historiography, edited by Gerd Althoff et al., Cambridge, 2002, pp. 139-66.

Goetz, Hans-Werner. "Wer sind eigentlich die Barbaren in den Barbarenreichen? Zur Kontinuität und Wandel des Barbarenkonzepts in der fränkischen Historiographie." Neue Wege der Frühmittelalterforschung. Bilanz und Perspektiven, edited by Walter Pohl et al., Verlag der Österreichischen Akademie der Wissenschaften, 2018, pp. 187-200.

Goldstein, Ivo. "Funkcija Jadrana u ratu Bizantskog carstva protiv Ostrogota 535. - 555. godine." Radovi Zavoda za hrvatsku povijest Filozofskoga fakulteta Sveučilišta u Zagrebu, vol. 37, no. 1, 2005, pp. 23-34.

Gračanin, Hrvoje. "Guduskani/Guduščani - Gačani: promišljanja o etnonimu Gačani i horonimu Gacka u svjetlu ranosrednjovjekovnih narativa i suvremenih historiografskih tumačenja." Gacka u srednjem vijeku, edited by Hrvoje Gračanin and Željko Holjevac, Institut društvenih znanosti Ivo Pilar; Područni centar Gospić, 2012, pp. 49-68.

Gračanin, Hrvoje. "Late Antique Dalmatia and Pannonia in Cassiodorus' Variae." Millennium, vol. 13, 2016, pp. 211-73.

Halsall, Guy. "Archaeology and Migration: Rethinking the Debate." Relicta, vol. monografien, no. 7, 2012, pp. 29-40.

Halsall, Guy. Barbarian Migrations and the Roman West, 376-568. Cambridge University Press, 2007.

Hamilton, Michelle M. Representing Others in Medieval Iberian Literature. Palgrave Macmillan, 2007.

Heng, Geraldine. The Invention of Race in the European Middle Ages. Cambridge University Press, 2018. 
Hoffmann, Richard C. "Outsiders by Birth and Blood: Racist Ideologies Around the Periphery of Medieval European Culture." The Medieval Frontiers of Latin Christendom: Expansion, Contraction, Continuity, edited by James Muldoon and Felipe Fernández-Armesto, Ashgate, 2008, pp. $149-80$.

Holquist, Michael. Dialogism: Bakhtin and His World. Routledge, 2002.

Hurbanič, Martin. The Avar Siege of Constantinople in 626: History and Legend. Palgrave Macmillan, 2019.

Hoppenbrouwers, Peter. "Medieval Peoples Imagined." Imagology: The Cultural Construction and Literary Representation of National Characters: A Critical Survey, edited by Manfred Beller and Joep Leerssen, Rodopi, 2007, pp. 45-62.

Hoppenbrouwers, Peter. "Such Stuff as Peoples Are Made on: Ethnogenesis and the Construction of Nationhood in Medieval Europe." The Medieval History Journal, vol. 9, no. 2, 2006, pp. 195-242. Jahner, Jennifer, et al. "Introduction." Medieval Historical Writing: Britain and Ireland, 500-1500, edited by Jennifer Jahner et al., Cambridge University Press, 2019, pp. 1-15.

Jones, W. R. "The Image of the Barbarian in Medieval Europe." Comparative Studies in Society and History, vol. 13, no. 4, 1971, 376-407.

Jordanes, The Origin and Deeds of the Goths. Translated by Charles C. Mierow. University of Calgary, people.ucalgary.ca/ vandersp/Courses/texts/jordgeti.html.

Kabir, Ananya Jahanara, and Deanne Williams, editors. Postcolonial Approaches to the European Middle Ages: Translating Cultures. Cambridge University Press, 2005.

Karbić, Damir, et al., editors. History of the Bishops of Salona and Split by Archdeacon Thomas of Split. Central European University Press, 2006.

Kempshall, Matthew S. Rhetoric and the Writing of History, 400-1500. Manchester University Press, 2011.

Khanmohamadi, Shirin A. In Light of Another's Word: European Ethnography in the Middle Ages. University of Pennsylvania Press, 2014. 
Kowalski, Wawrzyniec. "Rupture - Integration - Renewal: The Gathering in Dalma and the Creation of a Political Community in the Chronicle of the Priest of Dioclea." Slavia Meridionalis, vol. 19, 2019, pp. 1-28.

Kunčer, Dragana, editor. Gesta regum Sclavorum. Vol. 1, Istorijski institut; manastir Ostrog, 2009. Lampert-Weissig, Lisa. Medieval Literature and Postcolonial Studies. Edinburgh University Press, 2010.

Liebeschuetz, Wolf. East and West in Late Antiquity: Invasion, Settlement, Ethnogenesis and Conflicts of Religion. Brill, 2015.

López Quiroga, Jorge, et al., editors. Entangled Identities and Otherness in Late Antique and Early Medieval Europe. Oxford BAR Publishing, 2017.

Magdalino, Paul. "Aspects of Twelfth-Century Byzantine Kaiserkritik." Speculum, vol. 58, no. 2, 1983, pp. 326-46.

Makk, Ferenc. The Arpáds and the Comneni: Political Relations Between Hungary and Byzantium in the 12th Century. Akadémiai Kiadó, 1989.

Majnarić, Ivan. "Constituti sunt super gentes et regna: papinstvo i Nemanjići na početku 13. stoljeća." Стефран Првовенчани и његово доба (Stefan the First-Crowned and his Time), edited by Ivana Komatina, Istorijski institut Beograd, pp. 273-90.

Majnarić, Ivan. "In the Shadows of Empires: Early Medieval Croatia in the Ninth and Tenth centuries." History Compass, vol. 16, no. 7, 2018, pp. 1-11.

Matijević Sokol, Mirjana. "Archdeacon Thomas of Split (1200-1268): A Source of Early Croatian History." Review of Croatian History, vol. 3, no. 1, 2007, pp. 251-70.

Matijević Sokol, Mirjana. Toma Arhiđakon i njegovo djelo. Naklada Slap, 2002.

Neumann, Iver B. Uses of the Other: "The East" in European Identity Formation. University of Minnesota Press, 1999.

Ozkırımlı, Umut. Theories of Nationalism: A Critical Introduction. Palgrave Macmillan, 2010.

Peričić, Eduard. Sclavorum regnum Grgura Barskog. Kršćanska sadašnjost, 1991. 
Pohl, Walter. "Narratives of Origin and Migration in Early Medieval Europe: Problems of Interpretation." The Medieval History Journal, vol. 21, no. 2, 2018, pp. 1-30.

Ricoeur, Paul. Oneself as Another. University of Chicago Press, 1992.

Ricoeur, Paul. Time and Narrative. Vol. 3, University of Chicago Press, 1988.

Rubiés, Joan-Pau, editor. Medieval Ethnographies: European Perceptions of the World Beyond. Ashgate, 2009.

Simpson, Alicia. "Byzantium's Retreating Balkan Frontiers during the Reign of the Angeloi (1185-1203) A Reconsideration." The Balkans and the Byzantine World Before and After the C aptures of Constantinople, 1204 and 1453, edited by Vlada Stanković, Lexington Books, 2016, 322.

Spiegel, Gabrielle. The Past as Text: The Theory and Practice of Medieval Historiography. Johns Hopkins University Press, 1997.

Sokol, Vladimir. Medieval Jewelry and Burial Assemblages in Croatia: A Study of Graves and Grave Goods, ca. 800 to ca. 1450. Brill, 2016.

Southern, R. W. History and Historians: Selected Papers of R.W. Southern, edited by R. J. Bartlett. Blackwell, 2004.

Steindorff, Ludwig. “Jedno od gradilišta Nade Klaić: Ljetopis popa Dukljanina.” Nada Klaić i njezin znanstveni i nastavni doprinos razvoju historiografije, 29-30 November, 2013, Zagreb, Croatia, edited by Tomislav Galović and Damir Agičić, FF Press, 2014.

Stepanov, Tsvetelin. The Bulgars and the Steppe Empire in the Early Middle Ages: The Problem of the Others. Brill, 2010.

Stephenson, Paul. "Byzantine Conceptions of Otherness After the Annexation of Bulgaria (1018)."

Strangers to Themselves: The Byzantine Outsider, edited by Dion Smythe, Variorum Reprints, 2000.

Stephenson, Paul. Byzantium's Balkan Frontier. Cambridge University Press, 2000. 
Stouraitis, Yannis. "Byzantine Romanness: From Geopolitical to Ethnic Conceptions."

Transformations of Romanness, edited by Walter Pohl et al., De Gruyter, 2018, pp. 123-40.

Stouraitis, Yannis. "Roman Identity in Byzantium: A Critical Approach." Byzantinische Zeitschrift, vol. 107 , no. 1,2014 , pp. 175-220.

Todorov, Tzvetan. The Conquest of America: The Question of the Other. University of Oklahoma Press, 1999.

Turković, Tin, and Ivan Basić. "Nuove conoscenze sulla Liburnia Tarsaticensis nel contesto dello studio delle fonti geografiche." Atti del Centro di ricerche storiche-Rovigno, vol. 41, 2011, pp. 49102.

Ullman, Walter. Individuum und Gesellschaft im Mittelalter. Vandenhoeck \& Ruprecht, 1974.

Weeda, Claire. "Ethnic Identification and Stereotypes in Western Europe, circa 1100-1300." History Compass, vol. 12, 2014, pp. 586-606.

White, Hayden. The Content of the Text: Narrative Discourse and Historical Representation. The Johns Hopkins Press, 1990.

Whalin, Douglas. Roman Identity from the Arab Conquests to the Triumph of Orthodoxy. Palgrave Macmillan, 2020.

Wimmer, Andreas. Ethnic Boundary Making: Institutions, Power, Networks. Oxford University Press, 2013.

Wood, Ian. "A Byzantine Commonwealth, 476-553." Neue Wege der Frühmittelalterforschung. Bilanz und Perspektiven, edited by Walter Pohl et al., Verlag der Österreichischen Akademie der Wissenschaften, 2018, pp. 65-74.

Wood, Ian. "The Pagans and the Other: Varying Presentations in the Early Middle Ages." Network and Neighbours, vol. 1, no. 1, 2013, pp. 1-22.

Wood, Ian. "The Term 'barbarus' in Fifth-, Sixth-, and Seventh-Century Gaul.” Zeitschrift Für Literaturwissenschaft Und Linguistik, vol. 41, no. 4, 2011, pp. 39-50. 
Zerubavel, Eviatar. Time Maps. Collective Memory and the Social Shape of the Past. Chicago University Press, 2003.

Živković, Tibor. "Constantine Porhyrogenitus' kastra oikoumena in the Southern Slavs

Principalities." Istorijski časopis, vol. 57, 2008, pp. 9-28.

---, editor. Gesta regum Sclavorum. Vol. 2, Istorijski institut; manastir Ostrog, 2009.

---, editor. "The Origin of the Royal Frankish Annalist's Information about the Serbs in Dalmatia." Spomenica akademika Sime Chirkovicha, edited by Srđan Rudić, Istorijski institut, 2011, pp. 38198. 
[1] This paper has been supported by the Catholic University of Croatia under the project "Otherness as the Social and Cultural Determinant of the Croatian Past," no. HKS-2017-7 and by the Croatian Science Foundation under the project "Topography of Power: Eastern Adriatic Cities in Medieval Spheres of Power" (TOPOS), no. IP-2019-04-2055.

[2] "Many of the Christians ... chose rather to suffer persecution and poverty with them, and to thereby save their own souls, than to rejoice temporarily with the pagans and to thereby condemn their own souls" (CPD 1: 28-30).

[3] The body of literature on the problem of medieval historical writing, medieval historiography, and its genres is vast. For the purpose of this study, see, as an introduction to the problem, Jahner et al.; Deliyannis; Spiegel; Kempshall; Southern.

[4] In the following text, I will use the framework from the perspective of cultural and social representation. Although it requires special attention here in terms of medieval societies and worldviews, a useful example is presented in Barth. For a further elaboration of Barth's social and symbolic ethnic boundaries, see Wimmer. Focusing on strategies of making boundaries (the actors' selection of relevant boundaries) and belonging to a prestigious community, Wimmer pointed out the importance of understanding the dynamics of cultural differences by advocating a variability of nonethnic social forms (social networks, professional networks, social institutions, religious communities, etc.). This social closure - as he sees it - coupled with social power leads to a consensus on the categorizing ethnic boundaries. Among the vast literature on the Other, Otherness and Othering, see Todorov; Neumann 1-39; Holquist 13-37.

[5] For an overview of the field of postcolonial medieval studies, critique of the field, and application of its research methods, see Lampert-Weissig 1-30; Altschul; Cohen 1-17; Gaunt; Hamilton 1-14; Kabir et al.

[6] For the latest edition of the Chronicle and an overview of the studies which focus on it, see CPD 1 .

[7] For the English edition, see History of the Bishops. 
[8] For a useful methodological approach outside this frame, see Kowalski, and to some extent Matijević Sokol, Toma Arhiđakon; Ivić.

[9] The essential literature on the Early Medieval identities in the Eastern Adriatic is vast; for the purposes of this study, see Curta, "Southeastern Europe"; Curta, "Eastern Europe"; Budak; Curta, "A note on trade"; Džino; Gračanin, "Guduskani”; Ančić, "Church with incomplete biography"; Alimov, "Etnogenez Horvatov"; Sokol; Ančić et al.; Džino et al. For an overview of the problem of the Sorabi, see Živković, "The Origin"; for the new interpretation of the early medieval Sorabi in Dalmatia, see Džino 177-81.

[10] Regarding the problem of the (Romani) identity in the early medieval Eastern Adriatic cities and its relation to Romanness, see Džino; Borri, "Dalmatian Romans"; Whalin 193-96; Basić.

[11] The essential literature on identity and ethnicity in the late antiquity and the Early Middle Ages is also vast. For the purposes of this study, see Gillett; Liebeschuetz 85-100. For overviews of the issue, see: Garipzanov et al. 1-5; Halsall, Barbarian 10-34; Curta, "Some Remarks" 159-85; Halsall, "Archaeology and Migration" 29-40.

[12] For case studies of the medieval image of the Other and Othering, see Jones; Hoppenbrouwers, "Such Stuff”; Wood, "The Pagans”; Classen; Stephenson; Stepanov; Hoffmann; Khanmohamadi. Regarding medieval geographical otherness, see Quiroga et al. For detailed studies of a superior power's view of the Other, see Curta, "The Other Europe"; Rubiés; Hoppenbrouwers, "Medieval Peoples Imagined"; Heng; Bartra; Weeda.

[13] Regarding the individual in the Middle Ages, see Black; Morris; Ullman. It is also important to note that this differentiation sometimes revealed medieval historians themselves as individuals, even though their histories attempted to convey the view acceptable to their communities. This can be a useful starting point for examining how medieval historians created their works and to discern their own understanding of the past. At the same time, it shows whether the knowledge of the past lay within the community or elsewhere.

[14] Regarding (collective) memory and history, see White; Zerubavel. Regarding various aspects of memory in the Middle Ages, see Althoff et al.; Clanchy 255-94; Carruthers; Fentress and Wickham; Coleman; Brenner et al. 
[15] For an introductory overview of the problem of the editions, see CPD 2: 37-55. The historiographical discussion about the origins and the relations between the two editions (the Latin and the Croatian one) remains open. For this paper, the textual differences between the editions are not crucial.

[16] The most convincing identification so far points to Gregory, the archbishop of Bar from 1172 to 1196 (see Peričić). It was also suggested that the author might have been an anonymous Benedictine monk from the second half of the 12th century, John of Pian de Carpine, the famous papal envoy to the Great Khan of the Mongols and the archbishop of Bar from 1248 to 1252, the Cistercian Rudger (Rüdiger), the archbishop of Bar from 1299 to 1301, and even that the CPD was fabricated by Mauro Orbini in its entirety (CPD 2: 340-72; Bujan 5-38; Steindorff).

[17] His Historia Salonitana is the main and most distinguished narrative source for the history of Split and its archbishopric, the Kingdom of Croatia and Dalmatia, as well as for the entire Eastern Adriatic hinterland in the Early and High Middle Ages. Regarding Thomas and his work, see Matijević Sokol, Toma Arhiđakon; Matijević Sokol, "Archdeacon Thomas”.

[18] For more information, see Matijević Sokol, Toma Arhiđakon.

[19] “... multa milia hominum christianorum in ore gladii mortuasunt et plurimi captivi ductisunt ...” ( CPD 1: 10).

[20] "Multasque iniquitates et persecutiones faciendo christianis qui in civitatibus maritimis habitabant ..." (CPD 1: 18).

[21] “... Ratomirus, filius eius, qui inimicus nominis christiani extitit a pueritia. Coepitque ultramodum persequi christianos voluitque delere de terra et de regno suo nomen eorum. Multas quoque civitates eorum et loca destruxit et alias in servitutem redigens reservavit" (CPD 1: 26).

[22] "Quorum temporibus semper in persecutione fuerunt christiani et, quia innimici et persecutores christianorum, longum duximus narrare eorum iniquos actus et vitam quoniam ad meliora et delectabiliora tendere festinamus" (CPD 1: 28).

[23] “... multi christianorum ... eligentes magis cum eis sustinere persecutiones et penuriam et 
salvare animas suas, quam gaudere ad tempus cum gentilibus et vi eorum perdere animas" (CPD 1: $28-30)$.

[24] For detailed analyses of the late antique and early medieval "Gothicism," see Pohl.

[25] Regarding an older narrative template regarding the "Gothicism" of the CPD and the HS, see Matijević Sokol, Toma Arhiđakon 238; Džino 100-01. Regarding the unique conclusion that the HS preceded the CPD, see Borri, "Arrivano i barbari" 242-50. However, at least to some point, Borri seems to leave open the opposite possibility ("Arrivano i barbari" 242). Within the scope of this paper, it is also important to mention that many of Borri's analyses and remarks are very useful, but the mentioned conclusion is not convincing. Furthermore, Borri seems to have been seduced, to some extent, by the need to refute the unfounded history myth of older (Croatian) "national historiography" (the phrase is used with a descriptive meaning, see Özkırımlı 51-52) coupled with a misunderstanding of the HS and the CPD as narrative sources which recorded actual historical events and facts. In his argumentation, Borri also failed to position himself regarding the problem of the Goths mentioned in The Passion of St. Domnius from the second part of the eleventh century. As stated previously, I hold that the CPD is probably the older among the two.

[26] For the most notable example of the literary motive of Christianization as a turning point regarding the "barbarians" see Jordanes, ch. 25. However, it is necessary to note that the understanding and use of the Roman (Greek) concept of barbarus was extremely nuanced throughout the early middle ages. The term generally had negative connotations, but the motives used to express such connotations were subject to situational construction. The motive of Christianization of barbarians was used in a similar way, although more often from the 9th century on. It included various elements - sometimes several at the same time - such as a statement about the importance of the act of Christianization for the barbarians, a depiction of a Christian barbarian (emphasizing the differentness of the barbarians despite them becoming Christian), or indications of their non-Christian behaviour (as barbarus); see Goetz, "Wer sind"; Wood, "The Term 'barbarus'”; and the works cited in notes 2, 4, 12.

[27] For a similar argument, although regarding a different point of view, see Živković, "Constantine Porhyrogenitus". 
[28] Besides the works cited in note 2, regarding this framework of Thomas' and high medieval scholarly writing, see Althoff et al.; Booker; Kempshall; Agapitos and Mortensen; Deliyannis; Bak and Jurković; Garipzanov.

[29] Regarding the Thomas's relation to the town of Zadar and or the "Croatian" episcopate see Matijević Sokol, Toma Arhiđakon 151-57, 278-80, 286-89.

[30] The same conclusion can be found in the following studies, which nonetheless arrive at it through arguments that differ slightly from each other and the one presented in this paper: Matijević Sokol, Toma Arhiđakon 233-50; Džino 99-104; Alimov, "Gotsko-Slavjanskoe"; Ivić. The main difference in this paper is the methodology based on postcolonial medieval studies and the concept of Othering.

[31] Regarding the importance of literary motives Thomas used, see note 26.

[32] Here Constantinople represents the sacred centre, in accordance with the concept of the Byzantine oikoumene; for more information on this, see Wood. On the other hand, Slavs directly besieged Constantinople only in 626, as members of the Avar-led army; regarding the complex relation between Avars and Slavs and its possible effect on the perception of Slavs, see Hurbanič 126-28.

[33] On the problems related to the Ostrogoths in the Eastern Adriatic and Gothic Wars see Gračanin, "Late Antique" (with extensive overview of the relevant literature); Džino 29-31; Goldstein; Sarantis 89-91; Turković and Basić; Ciglenečki 205-22.

[34] Regarding the renovatio imperii and the situation in the Eastern Adriatic during the second half of the 12th century, see Magdalino; Simpson; Stephenson; Makk; Ferluga.

[35] The active hegemony is further confirmed by Thomas (HS 114) in his note on the mysterious Duke Relles, who was recently identified as a military commander of the Serbian "Grand Župan" Stephen Nemanja, who unsuccessfully tried to subdue Split in 1165 or 1166 . This happened at the time of Stephen Nemanja's - as Niketas Choniates (158) states - subjugation of Croatia and his taking possession of Dekataroi, and in the context of his insolence toward Manuel Komnenos. For more on that, see Ančić “Dux nomine Reles”; Majnarić, "Constituti sunt” 286-88. 
[36] See also Džino 160-61.

[37] Besides the episode with Relles, this is also evident in HS's description of the Kačići. This episode is too extensive to be analyzed here, and I will deal with it in another paper.

[38] Regarding the history of the south-eastern frontier of the Carolingian Empire in the first half of the 9th century, see Ančić et al.; Džino et al.; Džino. For an overview, see also Majnarić, "In the shadows."

[39] For a similar argument, although from a different point of view, see Alimov, "GotskoSlavjanskoe" 521.

\section{(c) $($ ) (9)}

Creative Commons Attribution-NonCommercial-NoDerivatives 4.0 International License 